\title{
PENELITIAN
}

\section{TINGKAT PENERAPAN PRINSIP 'ENAM TEPAT' DALAM PEMBERIAN OBAT OLEH PERAWAT DI RUANG RAWAT INAP}

\section{Kuntarti *}

\begin{abstract}
Abstrak
Penelitian ini bertujuan mengidentifikasi tingkat penerapan prinsip enam tepat dalam pemberian obat di ruang rawat inap. Prinsip enam tepat merupakan prinsip yang harus diperhatikan oleh perawat dalam pemberian obat untuk menghindari kesalahan pemberian obat dan keberhasilan pengobatan. Disain yang digunakan adalah deskriptif-eksploratif. Responden pada penelitian ini adalah perawat ruang rawat inap yang berperan dalam pemberian obat. Pengambilan sampel dengan cara purposive sampling berjumlah 81 orang dari 17 ruang rawat di RS Dr. Ciptomangunkusumo (RSCM) Jakarta. Data dikumpulkan dengan menyebarkan kuisioner untuk memperoleh data deskriptif tentang tingkat pengetahuan perawat mengenai prinsip enam tepat, tingkat penerapannya, dan faktor-faktor yang mempengaruhi penerapan tersebut. Hasil penelitian ini menunjukkan bahwa tingkat penerapan prinsip enam tepat oleh perawat secara umum baik. Urutan tingkat penerapan masing-masing komponen adalah (1) tepat pasien, (2) tepat waktu, (3) tepat obat, (4) tepat cara, (5) tepat dokumentasi, dan (6) tepat dosis. Namun, tingkat penerapan prinsip umum yang berkaitan dengan aspek keamanan bagi perawat masih rendah, yaitu sebagian besar perawat tingkat penerapannya rendah 51,9\%. Faktor internal yang mempengaruhi tingkat penerapan ini adalah karakteristik responden dan tingkat pengetahuan. Sedangkan faktor eksternalnya yaitu ketersediaan fasilitas dan Standar Operasional Prosedur (SOP), serta faktor supervisi dari atasan. Upaya mempertahankan dan meningkatkan tingkat penerapan prinsip ini dapat dilakukan dengan memperbanyak pelaksanaan pendidikan keperawatan berkelanjutan dan meningkatkan supervisi.
\end{abstract}

Kata kunci: prinsip enam tepat, kesalahan pemberian obat, pendidikan keperawatan berkelanjutan, supervisi

\begin{abstract}
The purpose of this study was to identify level of application of six rights principles in medication at ward. Six rights principles were the principles that must be attention by nurses in medication to avoid errors medication and to take a successful of medication. The design of this study was desciptive-explorative with purposive sampling. Eighty one (81) nurses who give medication from 17 (seventeen) wards were participated as respondens in this study. The study has been conducted in Dr. Cipto Mangunkusumo Hospital Jakarta by distributed a set of quisioner to get data about level of knowledge, level of application, and factors influencing in application of six rights principles in medication. The result of this study revealed that the most of nurses generalized had level of application of six rights principles good with the following were (1) right patient, (2) right time, (3) right drug, (4) right route, (5) right documentation, and (6) right dose. This study also revealed that the most of nurses (51.9\%) had the level of application of universal precaution were poor. The internal factors that influencing in application of six rights principles were respondens's characteristics and level of knowledge. The external factors were facilities and Standard Operational Procedure (SOP) for medication, and also supervision by a ward manager. To maintain and increase of the level of application should be done by extend the Continuing Nursing Education and increase supervision.
\end{abstract}

Key words: six rights principles, error in drug administration, continuing nursing education, supervision

\section{LATAR BELAKANG}

Pengobatan merupakan salah satu unsur penting dalam upaya penyembuhan penyakit dan pemulihan kesehatan. Perawat turut bertanggung jawab dalam memastikan bahwa pemberian obat tersebut aman bagi pasien dan membantu mengawasi efek pemberian obat tersebut. Untuk dapat menjalankan peranan ini, perawat harus dibekali dengan ilmu keperawatan (UU No.23 th. 1992 pasal 32 ayat (3)).

Dalam pemberian obat yang aman, perawat perlu memperhatikan lima tepat (five rights). Selama ini istilah five rights sering diterjemahkan sebagai lima benar. Namun, berdasarkan kajian yang penulis lakukan dan masukan dari seorang editor 
penerjemahan yang juga spesialis farmakologi klinik, five rights lebih tepat jika diterjemahkan menjadi lima tepat. Lima tepat ini meliputi tepat pasien (right client), tepat obat (right drug), tepat dosis (right dose), tepat waktu (right time), dan tepat rute (right route). Setiap ke"tepat"an memerlukan pengetahuan, keterampilan, dan tindakan keperawatan khusus (Abrams, 1995). Kee dan Hayes (2000) mengemukakan bahwa pengalaman menunjukkan ada five rights lainnya yang juga penting dalam praktek keperawatan profesional, yaitu: right assessment (tepat pengkajian), right documentation (tepat pencatatan), client's right to get education (hak klien mendapatkan pendidikan), right evaluation (tepat evaluasi), dan client's right to refuse medication (hak pasien untuk menolak). Kee dan Hayes menyebut penambahan ini dengan istilah five plus five rights.

Pada penelitian ini penulis memilih enam ketepatan yang harus diperhatikan oleh perawat dalam pemberian obat, yaitu lima tepat yang telah dikenal oleh perawat ditambah dengan tepat dokumentasi yang penting sebagai pertanggungjawaban secara legal tindakan yang telah dilakukan. Penerapan prinsip enam tepat (six rights) oleh perawat akan mempengaruhi keberhasilan pengobatan. Hal ini terutama akan tampak pada pasien yang dirawat di ruang rawat inap. Di ruang rawat inap, seorang perawat harus memberikan berbagai macam obat kepada beberapa pasien yang berbeda yang menjadi tanggung jawabnya. Untuk menghindari kesalahan dalam pemberian obat, perawat harus menerapkan prinsip "enam tepat" tersebut.

Data tentang kesalahan pemberian obat (medication error) di Indonesia belum dapat ditemukan. Darmansjah, (Nainggolan, 2003), ahli farmakologi dari FKUI menyatakan bahwa kasus pemberian obat yang tidak benar maupun tindakan medis yang berlebihan (tidak perlu dilakukan tetapi dilakukan) sering terjadi di Indonesia, hanya saja tidak terekspos media massa. Berdasarkan penelitian yang dilakukan oleh peneliti dari Auburn University di 36 rumah sakit dan nursing home di Colorado dan
Georgia, USA, pada tahun 2002, dari 3216 jenis pemberian obat, $43 \%$ diberikan pada waktu yang salah, 30\% tidak diberikan, $17 \%$ diberikan dengan dosis yang salah, dan $4 \%$ diberikan obat yang salah (Joint Commission on Accreditation of Health Organization (JCAHO), 2002). Peneliti pada penelitian ini juga mengemukakan hasil penelitian sebelumnya yang dilakukan oleh Institute of Medicine pada tahun 1999, yaitu kesalahan medis (medical error) telah menyebabkan lebih dari 1 (satu) juta cedera dan 98.000 kematian dalam setahun. Data yang didapat JCAHO juga menunjukkan bahwa 44.000 dari 98.000 kematian yang terjadi di rumah sakit setiap tahun disebabkan oleh kesalahan medis. (Kinninger \& Reeder, 2003).

Berdasarkan pengalaman praktik penelitian, peneliti juga beberapa kali menemui kasus kesalahan pemberian obat di suatu rumah sakit di Jakarta, antara lain pemberian antibiotika yang tidak sesuai dengan indikasi, obat diberikan pada waktu yang salah, pemberian obat yang sudah kadaluwarsa, dan pemberian obat yang tidak didokumentasikan.

\section{METODOLOGI}

Penelitian ini adalah penelitian deskriptif untuk melihat tingkat penerapan prinsip "enam tepat" dalam pemberian obat oleh perawat di 17 ruang rawat inap Rumah Sakit Dr. Cipto Mangunkusumo (RSCM), Jakarta. Populasi pada penelitian ini adalah perawat yang bertanggung jawab merawat pasien yang mendapat pengobatan. Sampel merupakan populasi setuju ikut dalam penelitian.

Pengambilan sampel dilakukan dengan cara purposive sampling, yaitu semua perawat yang sedang bertugas pada shift pagi saat pengumpulan data dan memenuhi kriteria dapat menjadi responden. Jumlah sampel yang diambil adalah 81 orang. Jumlah ini diperoleh dari rumus estimasi proporsi yang dikemukakan oleh Paul Leedy (Arikunto, 1988) dengan $\mathrm{Z}=1,96$, e $=0,1$, dan $\mathrm{P}=30 \%$. Pengumpulan data dilakukan dengan menyebarkan kuisioner yang mencakup pengkajian terhadap karakteristik perawat (umur, jenis kelamin, 
pendidikan, dan lama kerja), tingkat pengetahuan, dan tingkat penerapan prinsip 'enam tepat'.

Data yang diperoleh diolah menggunakan pendekatan kuantitatif dengan analisis univariat menggunakan komputer. Analisis univariat digunakan untuk mendeskripsikan variabel yang diteliti dengan mendapatkan besar proporsi, ukuran tengah (mean, median, dan modus), dan variasi (standar deviasi, interval, dan nilai minimal dan maksimal).

\section{HASIL PENELITIAN}

Pengambilan data dilakukan selama tiga bulan dengan responden sebanyak 81 orang. Hasil penelitian ini adalah sebagai berikut:

\section{A. Karakteristik responden}

Karakteristik responden yang diteliti adalah umur, jenis kelamin, tingkat pendidikan, dan lama kerja sebagai perawat. Perawat yang ikut dalam penelitian ini 95\% diyakini berumur antara 35,88-40,07 tahun, dengan rata-rata berumur 37,98 tahun. Diantaranya yang termuda berusia 22 tahun dan tertua 54 tahun. Berdasarkan jenis kelamin, perawat pria yang ikut dalam penelitian ini sebanyak 4 orang $(4,9 \%)$ dan yang wanita sebanyak 77 orang $(95,1 \%)$. Sedangkan berdasarkan tingkat pendidikan, perawat lulusan SPK/ SPR/DI Bidan sebanyak 27 orang (33,3\%), lulusan DIII sebanyak 52 orang $(64,2 \%)$, dan lulusan S1 sebanyak 2 orang $(2,5 \%)$. Berdasarkan lama kerja, responden yang telah bekerja sebagai perawat kurang dari 1 tahun sebanyak 8 orang $(9,9 \%), 1-5$ tahun sebanyak 18 orang $(22,2 \%)$, dan lebih dari 5 tahun sebanyak 55 orang $(67,9 \%)$.

\section{B. Tingkat pengetahuan}

Hasil penelitian ini menunjukkan bahwa dari 81 responden, 50 orang $(61,7 \%)$ belum pernah mengikuti seminar atau pelatihan tentang pemberian obat. Hanya 31 orang $(38,3 \%)$ yang sudah pernah mengikuti kegiatan tersebut. Tentang yang berperan dalam pemberian obat, 40 orang $(49,4 \%)$ menyatakan bahwa yang paling berperan dalam pemberian obat kepada pasien adalah dokter, 34 orang $(42,0 \%)$ adalah perawat, 5 orang $(6,2 \%)$ adalah keluarga pasien, dan
2 orang $(2,5 \%)$ adalah apoteker. Sedangkan mengenai pengenalan terhadap istilah 'enam tepat', 30 orang (37\%) menyatakan mengenal istilah tersebut dan dapat menyebutkan dengan benar, 46 orang $(56,8 \%)$ hanya mengenal lima tepat, enam tepat tanpa tepat dokumentasi, dan 5 orang $(6,2 \%)$ tidak tahu. Dari kasus tentang pemberian obat yang diberikan dalam kuisioner, hasil yang didapat responden adalah sebagai berikut: 54 orang $(66,7 \%)$ mendapat nilai 100 , 21 orang $(25,9 \%)$ mendapat nilai 80,2 orang $(2,5 \%)$ mendapat nilai 60 , dan 4 orang $(4,9 \%)$ mendapat nilai 40. Sehingga, responden yang nilai pencapaiannya kurang dari 60 sebanyak 4 orang $(4,9 \%)$.

\section{Tingkat penerapan prinsip 'enam tepat'}

Hasil penelitian ini, secara umum menunjukkan tingkat penerapan sebagai berikut: dari 81 responden, tingkat penerapan prinsip 'enam tepat' dalam pemberian perawat oleh 35 orang $(43,2 \%)$ tinggi, 44 orang $(54,3 \%)$ sedang, dan 2 orang $(2,5 \%)$ rendah. Sedangkan untuk setiap komponen ketepatan, tingkat penerapannya tampak pada Tabel 1 .

Tabel 1.

Tingkat penerapan komponen prinsip 'enam tepat' dalam pemberian obat oleh perawat di Ruang Rawat Inap RSCM

$(n-81)$

\begin{tabular}{|c|c|c|c|c|c|c|}
\hline \multirow{3}{*}{ Komponen } & \multicolumn{6}{|c|}{ Tingkat Penerapan } \\
\hline & \multicolumn{2}{|c|}{ Tinggi } & \multicolumn{2}{|c|}{ Sedang } & \multicolumn{2}{|c|}{ Rendah } \\
\hline & Jumlah & $\%$ & Jumlah & $\%$ & Jumlah & $\%$ \\
\hline Tepat Obat & 61 & 75,3 & 19 & 23,5 & 1 & 1,2 \\
\hline Tepat Dosis & 16 & 19,8 & 54 & 66,7 & 11 & 13,6 \\
\hline Tepat Waktu & 30 & 37,0 & 51 & 63,0 & 0 & 0 \\
\hline Tepat Pasien & 73 & 90,1 & 8 & 9,9 & 0 & 0 \\
\hline Tepat Cara/Rute & 36 & 44,4 & 42 & 51,9 & 3 & 3,7 \\
\hline Tepat Dokumentasi & 48 & 59,3 & 26 & 32,1 & 7 & 8,6 \\
\hline
\end{tabular}

Tabel 2.

Tingkat penerapan universal precaution dalam pemberian obat oleh perawat di Ruang Rawat Inap RSCM ( $\mathrm{n}=81$ )

\begin{tabular}{ccc}
\hline Tingkat penerapan & Jumlah & Prosentase \\
\hline Rendah & 42 & 51,9 \\
Sedang & 38 & 46,9 \\
Tinggi & 1 & 1,2 \\
\hline Total & 81 & 100,0 \\
\hline
\end{tabular}


Kelompok perilaku/ tindakan yang tercakup dalam setiap komponen prinsip-prinsip di atas, dapat dilihat pada Tabel 3.

Tabel 3.

Tindakan-tindakan dalam komponen prinsip 'enam tepat'

\section{Tepat Obat}

$\checkmark \quad$ Mengecek program terapi pengobatan dari dokter

$\checkmark \quad$ Menanyakan ada tidaknya alergi obat

$\checkmark \quad$ Menanyakan keluhan pasien sebelum dan setelah memberikan obat

$\checkmark \quad$ Mengecek label obat 3 kali (saat melihat kemasan, sebelum menuangkan, dan setelah menuangkan obat) sebelum memberikan obat

$\checkmark$ Mengetahui interaksi obat

$\checkmark$ Mengetahui efek samping obat

$\checkmark \quad$ Hanya memberikan obat yang disiapkan diri sendiri

\section{Tepat dosis}

$\checkmark \quad$ Mengecek program terapi pengobatan dari dokter

$\checkmark$ Mengecek hasil hitungan dosis dengan perawat laian (double check)

$\checkmark$ Mencampur/mengoplos obat sesuai petunjuk pada label/ kemasan obat

\section{Tepat waktu}

$\checkmark \quad$ Mengecek program terapi pengobatan dari dokter

$\checkmark$ Mengecek tanggal kadaluarsa obat

$\checkmark$ Memberikan obat dalam rentang 30 menit sebelum sampai 30 menit setelah waktu yang diprogramkan

\section{Tepat pasien}

$\checkmark \quad$ Mengecek program terapi pengobatan dari dokter

$\checkmark \quad$ Memanggil nama pasien yang akan diberikan obat

$\checkmark$ Mengecek identitas pasien pada papan/ kardeks di tempat tidur pasien yang akan diberikan obat

\section{Tepat cara pemberian}

$\checkmark \quad$ Mengecek program terapi pengobatan dari dokter

$\checkmark$ Mengecek cara pemberian pada label/ kemasan obat

$\checkmark$ Pemberian per oral: mengecek kemampuan menelan, menunggui pasien sampai meminum obatnya

$\checkmark$ Pemberian melalui intramuskular: tidak memberikan obat $>5 \mathrm{cc}$ pada satu lokasi suntikan

\section{Tepat dokumentasi}

$\checkmark \quad$ Mengecek program terapi pengobatan dari dokter

$\checkmark$ Mencatat nama pasien, nama obat, dosis, cara, dan waktu pemberian obat

$\checkmark$ Mencantumkan nama/inisial dan paraf

$\checkmark$ Mencatat keluhan pasien

$\checkmark$ Mencatat penolakan pasien

$\checkmark \quad$ Mencatat jumlah cairan yang digunakan untuk melarutkan obat (pada pasien yang memerlukan pembatasan cairan)

$\checkmark$ Mencatat SEGERA setelah memberikan obat

\section{Universal precaution}

$\checkmark \quad$ Mencuci tangan sebelum dan sesudah memberikan obat

$\checkmark \quad$ Menggunakan sarung tangan (handschoen) ketika memberikan obat secara parenteral

$\checkmark \quad$ Membuang jarum suntik bekas pada tempat khusus dalam keadaan terbuka

Dari berbagai sumber: Abrams (1995); Chernecky (2002); Kee \& Hayes (2000); and Kozier, Erb, \& Oliveri (1995) 
D. Faktor-faktor yang mempengaruhi penerapan prinsip 'enam tepat'

Faktor internal yang mempengaruhi tingkat penerapan prinsip 'enamtepat', yaitu karakteristik perawat dan tingkat pengetahuan telah disampaikan sebelumnya. Untuk faktor eksternal, pada penelitian ini, dari 81 responden yang menilai ketersediaan fasilitas pemberian obat baik sebesar 11,1\% (9 orang). Sedangkan faktor supervisi, yang dalam hal ini dilakukan oleh ketua tim atau ketua grup dan kepala ruangan, yang menilai baik sebesar 29,6\% (24 orang). Sementara itu, faktor kebijakan institusi dalam pemberian obat, yang dalam hal ini dilihat dari ketersediaan dan penerapan Standar Operasional Prosedur (SOP), dinilai baik oleh $32,1 \%$ responden (26 orang).

\section{PEMBAHASAN}

Dari hasil penelitian ini diperoleh data bahwa tingkat penerapan prinsip 'enam tepat' dalam pemberian obat oleh perawat di 17 ruang rawat inap RSCM secara umum baik, yaitu 35 orang $(43,2 \%)$ tingkat penerapannya tinggi, 44 orang $(54,3 \%)$ sedang, dan 2 orang $(2,5 \%)$ rendah. Untuk setiap ketepatan memiliki tingkat penerapan yang berbeda-beda.

Tepat pasien memiliki tingkat penerapan yang paling tinggi, yaitu dari 81 responden yang tingkat penerapannya tinggi mencapai $90,1 \%$. Hal ini mungkin dipengaruhi oleh karakteristik responden yang sebagian besar wanita $(95,1 \%)$, berpendidikan DIII keperawatan $(64,2 \%)$, dan lama kerja lebih dari 5 tahun (67,9\%). Dengan karakteristik responden seperti itu, penerapan kemampuan komunikasi perawat lebih baik karena salah satu tindakan yang perlu dilakukan untuk menjamin ketepatan pasien ini adalah memanggil nama pasien ketika akan memberikan obat (Abrams, 1995). Namun hal ini masih perlu dibuktikan dengan penelitian yang menunjukkan hubungan antara faktorfaktor tersebut.

Komponen yang tingkat penerapannya terbaik kedua adalah tepat waktu. Tindakan untuk meyakinkan bahwa obat diberikan pada waktu yang tepat, perawat sebaiknya memberikan obat dalam waktu 30 menit sebelum dan sesudah waktu yang terjadwal jika interval pemberian obat lebih dari 2 jam (Chernecky, 2002, dan Kee \& Hayes, 2000). Perawat juga harus mempertimbangkan efek yang akan terjadi setelah pemberian obat dengan waktu pemberian. Tingkat penerapan tepat waktu, yang tingkat penerapannya tinggi sebesar 37,0\% (30 orang), sedang 63,0\% (51 orang). Hasil ini berbeda dengan hasil penelitian yang dilakukan oleh peneliti dari Auburn University di 36 rumah sakit dan nursing home di Colorado dan Georgia, USA, pada tahun 2002, bahwa dari 3216 jenis pemberian obat, $43 \%$ diberikan pada waktu yang salah (JCAHO, 2002).

Tingkat penerapan yang cukup baik juga tampak pada penerapan ketepatan obat dan cara atau rute pemberian obat. Tindakan untuk meyakinkan bahwa perawat memberikan obat yang tepat kepada pasien, perawat harus mampu mengintepretasikan program terapi pengobatan dokter secara tepat. Selain itu, perawat juga dianjurkan membaca label obat paling sedikit tiga kali sebelum memberikan obat, yaitu saat melihat botol atau kemasan obat, sebelum menuangkan obat, dan sesudah menuangkan obat (Kee \& Hayes, 2000). Hasil penelitian ini menunjukkan bahwa untuk penerapan tepat obat, hanya 1 orang $(1,2 \%)$ yang rendah. Sebagian besar, yaitu sebanyak 61 orang $(75,3 \%)$ tingkat penerapannya tinggi dan yang sedang sebanyak 19 orang $(23,5 \%)$. Begitu juga dengan dalam ketepatan cara pemberian obat, hanya 3 orang $(3,7 \%)$ yang tingkat penerapannya rendah. Sebagian besar memiliki tingkat penerapan yang baik, yaitu yang tingkat penerapannya sedang 42 orang $(51,9 \%)$ dan tinggi sebanyak 36 orang $(44,4 \%)$. Tindakan untuk menjamin bahwa cara atau rute yang digunakan untuk memberikan obat adalah tepat, perawat harus yakin bahwa bentuk obat sesuai dengan cara yang tertulis dalam program terapi pengobatan (Chernecky, 2002). Untuk pemberian obat secara oral (melalui mulut), perawat harus mengkaji kemampuan klien dalam menelan dan tidak meninggalkan pasien sebelum yakin pasien benar-benar menelan obatnya. Perawat juga harus menggunakan teknik aseptik ketika memberikan obat. Untuk pemberian obat secara parenteral, perawat harus menggunakan teknik steril, dan mengikuti cara atau instruksi penyiapan dan pemberian dari perusahaan pembuat obat (Kee \& Hayes, 2000).

Namun, masih ada komponen dari prinsip 'enam tepat' yang tingkat penerapannya cukup banyak yang rendah, yaitu penerapan tepat dosis dan 
tepat dokumentasi. Untuk meyakinkan bahwa obat yang diberikan kepada pasien tepat dosisnya, perawat harus mampu menghitung dosis dengan tepat dan melakukan koreksi ulang (double-checking) hasil hitungannya dengan perawat lain atau dengan dokter yang memberikan instruksi (Chernecky, 2002). Selain itu, perawat harus mampu menginterpretasikan singkatan atau kependekan (abbreviation) dan istilah-istilah yang ada dalam instruksi secara akurat dan tepat (Abrams, 1995). Hal yang penting juga adalah perawat juga harus mengambil sejumlah obat sesuai dengan hasil perhitungan dengan tepat untuk memberikan obat dalam dosis yang tepat kepada pasien. Hasil penelitian ini menunjukkan bahwa untuk komponen tepat dosis, yang tingkat penerapannya tinggi hanya 16 orang $(19,8 \%)$. Hasil ini sejalan dengan yang ditemukan pada penelitian yang dilakukan oleh peneliti dari Auburn University, USA, pada tahun 2002, bahwa dari 3216 jenis pemberian obat, $17 \%$ diberikan dengan dosis yang salah (JCAHO, 2002). Sedangkan untuk ketepatan dokumentasi pemberian obat, yang tingkat penerapannya tinggi sebanyak 48 orang $(59,3 \%)$, sedang 26 orang $(32,1 \%)$, dan rendah 7 orang $(8,6 \%)$. Dokumentasi pemberian obat yang tepat mencakup aspek lima tepat (pasien, obat, dosis, cara pemberian, dan waktu pemberian) serta respons klien terhadap pengobatan. Aspek legal dalam pendokumentasian yang perlu diperhatikan antara lain nama atau inisial dan tanda tangan atau paraf perawat yang memberikan. Prinsip yang perlu diterapkan oleh perawat yaitu mencatat yang dikerjakan diri sendiri dan tidak mencatat apa yang dikerjakan oleh orang lain (Abrams, 1995).

Tingkat penerapan prinsip 'enam tepat' dalam pemberian obat oleh perawat di 17 ruang rawat inap RSCM yang telah dikemukakan di atas, mungkin dipengaruhi oleh beberapa faktor. Pada penelitian ini faktor-faktor yang teridentifikasi adalah faktor internal, yaitu karakteristik responden dan tingkat pengetahuan; dan faktor eksternal, yaitu ketersediaan fasilitas dan SOP, serta berjalannya supervisi dari atasan. Pada tingkat pengetahuan, penelitian ini menunjukkan bahwa kemampuan responden dalam menyelesaikan kasus tentang pemberian obat pada kuisioner sebagian besar baik. Hasil tersebut mungkin dipengaruhi oleh sebagian besar responden yang merupakan perawat berpendidikan D-III (64,2\%). Hal ini juga dibuktikan dengan pengenalan responden terhadap istilah 'enam tepat'. Padahal hasil penelitian ini menunjukkan bahwa dari 81 responden, hanya 31 orang $(38,3 \%)$ yang sudah pernah mengikuti kegiatan seminar atau pelatihan tentang pemberian obat, dan sebagian besar $(61,7 \%)$ belum pernah mengikutinya. Tingkat penerapan prinsip 'enam tepat' yang baik, yang dicapai oleh sebagian besar responden pada penelitian ini juga mungkin disebabkan oleh pemahaman mereka terhadap besarnya peranan perawat dalam pemberian obat.

Walaupun tingkat penerapan terhadap prinsip 'enam tepat' dalam pemberian obat oleh sebagian besar perawat baik, namun ternyata tidak didukung dengan tingkat penerapan prinsip 'universal precaution' yang sebagian besar perawat memiliki tingkat penerapan rendah $(51,9 \%)$. Padahal prinsip ini penting diperhatikan dan diterapkan oleh perawat terutama untuk keamanan (safety) bagi perawat.

Dari hasil penelitian ini tampak bahwa tingkat penerapan prinsip 'enam tepat' dalam pemberian obat yang sebagian besar cukup baik, lebih dipengaruhi oleh faktor internal perawat, yaitu karakteristik responden dan tingkat pengetahuan. Hal ini tampak dari pendapat mereka tentang faktor-faktor eksternal yang teridentifikasi saat penelitian, yaitu masih 42\% (34 orang) yang menilai ketersediaan fasilitas pemberian obat kurang. Dari faktor supervisi, yang dalam hal ini dilakukan oleh ketua tim atau ketua grup dan kepala ruangan, masih 25,9\% (21 orang) yang menilai kurang. Sedangkan faktor kebijakan institusi dalam pemberian obat, yang dalam hal ini dilihat dari ketersediaan dan penerapan SOP, yang menilai kurang sebanyak 23,5\% (19 orang).

\section{KESIMPULAN}

Prinsip dasar dalam pemberian obat yang aman dan akurat dengan memperhatikan prinsip "enam tepat" (six rights) penting untuk diterapkan dalam memberikan asuhan keperawatan. Hasil penelitian ini menunjukkan bahwa secara umum tingkat penerapan prinsip 'enam tepat' dalampemberian obat oleh perawat di ruang rawat inap RSCM baik. Untuk setiap ketepatan memiliki tingkat penerapan yang berbeda-beda. Urutan tingkat 
penerapan setiap komponen adalah sebagai berikut: (1) tepat pasien, (2) tepat waktu, (3) tepat obat, (4) tepat cara, (5) tepat dokumentasi, dan terakhir (6) tepat dosis. Namun, tingkat penerapan prinsip umum (universal precaution) yang berkaitan dengan aspek keamanan (safety) bagi perawat masih rendah.

Dari hasil penelitian ini juga tampak bahwa tingkat penerapan prinsip 'enam tepat' dalam pemberian obat yang sebagian besar cukup baik, lebih dipengaruhi oleh faktor internal perawat, yaitu karakteristik responden dan tingkat pengetahuan. Faktor eksternal yang teridentifikasi mempengaruhi tingkat penerapan dalam penelitian ini adalah ketersediaan fasilitas pemberian obat, supervisi oleh ketua tim atau ketua grup dan kepala ruangan masih kurang, dan kebijakan institusi dalam pemberian obat yang dalam hal ini dilihat dari ketersediaan dan penerapan SOP.

Tingkat penerapan prinsip 'enam tepat' dalam pemberian obat oleh perawat yang sudah baik pada penelitian ini perlu dipertahankan. Sedangkan tingkat penerapan komponen yang masih kurang, yaitu tepat dosis dan dokumentasi masih harus ditingkatkan. Selain itu juga tingkat penerapan prinsip universal precaution dalam pemberian obat sangat perlu ditingkatkan baik untuk kepentingan pasien maupun untuk kepentingan perawat sendiri dalam aspek keamanan (safety). Usaha mempertahankan dan meningkatkan penerapan prinsip 'enam tepat' ini dapat dilakukan dengan berbagai cara. Pertama, mengadakan pendidikan keperawatan berkelanjutan (continuing nursing education) yang memasukkan tindakantindakan yang penting dilakukan oleh perawat dalam menerapkan prinsip 'enam tepat'. Kedua, peningkatan aspek pengawasan dan supervisi dari ketua tim dan kepala ruangan kepada pelaksana dalam pemberian obat. Ketiga, melengkapi fasilitas dasar yang penting untuk pemberian obat, terutama untuk penerapan 'universal precaution', seperti: sarung tangan (handschoen), tempat khusus pembuangan jarum suntik, dan obat-obat untuk keadaan gawat darurat. Serta yang keempat, menyusun SOP tentang pemberian obat serta penanganan kesalahan pemberian obat untuk diterapkan.

Untuk masa yang akan datang, perlu dilakukan penelitian tentang hubungan antara tingkat penerapan dengan faktor-faktor yang mempengaruhinya. Akan lebih baik jika melakukan observasi terhadap penerapan perilaku pemberian obat untuk melihat tingkat penerapan yang lebih objektif. (EN)

\section{Penelitian dibiayai program Peneliti Muda III FIK-UI tahun anggaran 2003-2004}

* Kuntarti, SKp: staf pengajar Kelompok Keilmuan Dasar Keperawatan dan Keperawatan Dasar Fakultas Ilmu Keperawatan Universitas Indonesia (DKKD FIK-UI)

\section{KEPUSTAKAAN}

Abrams, AC. (1995). Clinical drug therapy: Ationales for nursing practice. $4^{\text {th }}$ ed. Philadelphia: J.B. Lippincott Co.

Arikunto, Suharsini. (1998). Prosedur penelitian: Suatu pendekatan praktek. Edisi revisi IV. Jakarta: PT Rineka Cipta.

Blicharz, M.E. editor (1994). Pharmacology. New York: Delmar Publishers inc.

Chernecky, C., et al. (2002). Real-world nursing survival guide: Drug calculations and drug administration. Philadelphia: WB Saunders Co.

Joint Commission on Accreditation of Health Organization. (2002). Research shows disturbing drug error rates. Diambil 29 Januari 2004, dari http://www.glencoe.com/ps/health/ article.php4?article Id $=518$

Kee, JL \& Hayes, ER (2000). Pharmacology: $a$ Nursing process approach. $3^{\text {rd }} \mathrm{ed}$. Philadelphia: WB Sauders Co.

Kinninger, T \& Reeder, L. (2003). Establishing ROI for technology to reduce medication errors is both a science and an art. Diambil 8 Desember 2003, dari http://www.bridgemedical.com/ media_cov_2_03.shtml.

Kozier, Erb, \& Olivieri. (1995). Fundamentals of nursing: Concepts, process, and practice. California: Addison-Wesley.

Nainggolan, Nancy. (2003). Pemakaian antibiotik dosis tinggi merusak ginjal Anne. Suara Pembaruan, 9 Desember 2003. 